\title{
次世代のアカデミア創薬を担う若手のカ
}

\author{
松丸尊紀, $*, a, \dagger$ 安田大輔 $b$
}

\section{Young Innovators Driving the Next Generation of Academic Drug Discovery}

\author{
Takanori Matsumaru ${ }^{*, a, \dagger}$ and Daisuke Yasuda ${ }^{b}$ \\ ${ }^{a}$ Graduate School of Pharmaceutical Sciences, Hokkaido University; Kita 12 Nishi 6, Kita-ku, Sapporo 060-0812, \\ Japan: and ${ }^{b}$ Department of Pharmaceutical Sciences, Faculty of Pharmacy, Keio University; \\ 1-5-30 Shibakoen, Minato-ku, Tokyo 105-8512, Japan.
}

平成 28 年度で終了を迎えた, 文部科学省及び国 立研究開発法人日本医療研究開発機構（Japan Agency for Medical Research and Development; AMED）による 5 カ年プロジェクト「創薬等支援 技術基盤プラットフォーム事業」は，迅速な医薬品 等の実用化を可能とする全国規模のプラットフォー ムを形成することを目的とし，ライフサイエンス研 究者を支援してきた。本事業は，タンパク質の構 造・機能を解析する解析拠点, ゲノムやタンパク質 のデータベースを活用する情報拠点，タンパク質の 機能を制御する化合物の探索・改変を行う制御拠点 の 3 つの拠点から成り立つ. 本シンポジウムは, 制 御拠点にて活躍する若手研究者にて構成されている.

制御拠点の主題となる化合物の探索・改変は, 製

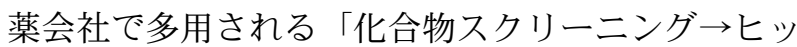
卜化合物 $\rightarrow$ 誘導体合成 $\rightarrow$ 活性評価」という研究プロ セスを用いて研究を進めてきた．大学の一研究室が このプロセスのすべてを担うことは困難であるが, 全国に広がる制御拠点が協同し，東京大学を始めと する各拠点独自の化合物ライブラリーを活用するこ とで一連の研究の迅速な展開を可能とした. 本シン ポジウムにおいても講演者の方々のご発表は化合物 スクリーニングと化合物合成の研究が入り交じる, 独自性の高い創薬研究であった.

最初に九州大学大学院薬学研究院の山下智大先生

${ }^{a}$ 北海道大学大学院薬学研究院（ T060-0812 札幌市北 区北 12 条西 6), $b$ 慶應義塾大学薬学部 (T105-8512 東京都港区芝公園 1-5-30)

現所属: ‘慶應義塾大学理工学部（下223-8522 横浜市 港北区日吉 3-14-1)

*e-mail: tmatsumaru@ pharm.hokudai.ac.jp 日本薬学会第 137 年会シンポジウム S13 序文
より, 痛みの研究として ATP 受容体を標的とした 化合物スクリーニングの手法やヒット化合物におけ る動物実験の結果と, 新たな創薬戦略であるグリー ンファルマ研究についてご紹介頂いた，次に，東北 大学大学院薬学研究科の可野邦行先生より, 東北大 学の独自化合物ライブラリー及び，ライブラリーを 用いた実施例として，生理活性脂質リゾホスファチ ジン酸（lisophosphatidic acid; LPA）の受容体の 1 つである LPA3 の antagonist の探索についてご紹 介頂いた. 続いて, 東京大学大学院工学系研究科の 長門石 曉先生より, 物理学的解析によるスクリー ニングの技術開発と得られてきたヒット化合物の精 密な相互作用解析に関する成果についてご紹介頂い た. 北海道大学大学院薬学研究院の野村尚生先生か らは，小胞体ストレスタンパク質である endoplasmic reticulum oxidoreductin $1 \alpha(\mathrm{ERO} 1 \alpha)$ に対し て，種々のスクリーニング系に適用することで数種 の相互作用化合物を同定したことをご紹介頂いた.

さらに東京薬科大学生命科学部の藤川雄太先生よ り，新規エクジステロイド生合成因子を標的とした 創農薬研究として, ハイスループットスクリーニン グ系の構築などについてご紹介頂いた．東京医科歯 科大学生体材料工学研究所の吉田 優先生より, 光 親和性標識法であるジアジドプローブ法の高度化を 目指した分子連結法の開発についてご紹介頂いた。 最後に, 慶應義塾大学薬学部の安田大輔先生より, タンパク質間相互作用（protein-protein interaction; PPI）阻害剂の Hit to Lead 研究として, Keap1Nrf2 PPI 阻害剂の合成研究及び代謝安定性の評価 についてご紹介頂いた.

以上のように，本シンポジウムは「創薬」をキー 
ワードに，分野に囚われず，多様性のある講演がな された．創薬研究を展開する上では，1つの専門分 野の研究だけではなく, 様々な分野の研究につい て, 研究者同士が相互理解することが重要である. 本シンポジウムのような総合的な議論の場が, アカ デミア創薬の更なる発展を促す一助になれば幸いで ある．また，創薬等支援技術基盤プラットフォーム
事業は平成 29 年度より創薬等ライフサイエンス研 究支援基盤事業として新たに開始され，ますますの 創薬基盤構築の加速化が期待されている.

最後に, 本シンポジウムの開催, 並びに本誌上シ ンポジウムの掲載にあたり, 大変貴重な機会を与え て頂いた日本薬学会関係各位及び，シンポジスト各 位に厚く御礼申し上げたい。 